\title{
Robustness of Price Perception: How Strong are Anchoring, Left-Digit- and Framing-Effects when Promoting Sales Offers?
}

\author{
Andreas Krämer \\ Correspondence: Andreas Krämer, BiTS-Business and Information Technology School GmbH, University of Applied \\ Sciences, Iserlohn, Germany and exeo Strategic Consulting AG, Bonn, Germany
}

Received: September 22, 2015 Accepted: October 10, 2015 Online Published: October 13, 2015

doi:10.11114/bms.v2i1.1137

URL: http://dx.doi.org/10.11114/bms.v2i1.1137

\begin{abstract}
While the large number of publications on behavioral pricing and partly spectacular results suggest that it is easily possible to influence parameters in the consumers' price perception (for example, by providing price anchors as competitive prices, 99-price endings, information on a relative or absolute saving or information on availability of the prices by the suppliers), this empirical study based on experimental designs comes to a contrary conclusion: it turns out that the assessment of perceived value for money and cheapness for different sales promotion campaigns in Germany (train ticket, smartphone flat rate, filter coffee) is amazingly robust and that psychological factors tested in different experiments have a relatively low impact. The theoretical, practical and research implications of these findings are discussed.
\end{abstract}

Keywords: behavioral pricing, framing, "left-digit-effect", odd ending pricing, anchoring and framing effects

\section{Introduction}

A decision to make a purchase can be influenced by many factors. One of the most powerful influences on purchase decisions is price. The classic price theory assumes that reducing the price of a product will lead to an increase in demand. A series of experiments with focus on behavioral economics could demonstrate in recent years that relationships between price and demand can be unexpected. One study took a look at comparable price points for items like women's clothing, using options such as $\$ 34$ vs. $\$ 39$, only to find that the higher $\$ 39$ price shockingly outsold the cheaper price point by $24 \%$. The same product sold more units with a price of $\$ 39$ then with a price of $\$ 34$ (Anderson \& Simester, 2003). The study results seem to support the proliferation of odd-ending prices (9-endings) in practice. Published studies report that from 30\% (Anderson \& Simester, 2003) up to $65 \%$ (Bray \& Harris, 2006; Simon, 2013) of retail prices end in 9 . The preponderance of 9-ending prices is not a new phenomenon and has been the subject of much comments and discussions over the past 70 years or even longer.

Other studies show that minor changes in price can have a strong impact on price perception. In other words, $\$ 3.99$ is perceived as much lower than $\$ 4.00$ but $\$ 3.69$ is not perceived as much lower than $\$ 3.70$. The reason for this: we look at numbers, we translate and map them onto a mental number line and essentially ignore the right-most digits (Schindler \& Kibarian, 1993).

However, odd ending prices are just one facet of psychological pricing. Other study results show that the presentation of the price, its length, color and font size can influence how consumers perceive the price. In his overview article Larson (2014) presented no less than 50 different tools for behavioral pricing.

\subsection{Particular Psychological Effects with Expected Strong Impact on Price Perception}

Subsequently, the focus should be on 3 areas of psychological pricing, which are particularly relevant in practice:

(1) Anchoring effect: When consumers receive objective information about a product, they tend to translate it into subjective values indicating whether this is expensive or inexpensive. This translation requires that they compare it to an internal standard that is based on prices of similar stimuli encountered in the past. This standard is typically referred to as a reference price and its effects are construed in terms of adaptation level theory (Helson 1964). As Janiszewski and Lichtenstein (1999) state, it is well accepted in the behavioral pricing literature that a consumer's perception of the attractiveness of a market price depends on a comparison of the market price to an internal reference price. At the same time an external reference price could be relevant for the consumer, for example where the price of a competitor's 
product is known.

(2) Price-ending-effect: If a price is $\$ 9.99$ whereas another is $\$ 10$, although the real difference is only one Cent, the fact that the number 10 has two digits, its perceived value is a lot higher than it really is. Therefore, the consumers think they are receiving great savings by going for the $\$ 9.99$. It is often described as the "left-digit-effect" (Thomas \& Morwitz, 2005), when the leftmost digit of the compared prices differ. However, there is evidence that the use of 99 in the right-most two digits of a retail price may create a low-price image in the minds of consumers (Schindler \& Kibarian 2001).

(3) Further pricing tactics often used as framing-effect like limited availability ("Scarcity effect") and notices of absolute and relative savings. Suggesting that quantities are limited due to market conditions (e.g. "only while supplies last") can influence product perception. If consumers are promotion-focused (either from product attributes or marketing messages), supply-based scarcity (e.g. purchase limits) can motivate more purchases (Ku, Kuo \& Kuo, 2012).

\subsection{Study Background and Objectives}

Advertising with a focus on price plays a relatively strong role in current media campaigns in Germany. For example, Deutsche Bahn (German railway) advertised an exclusive offer: "The best special fare (Sparpreis) there has ever been." (July 2015). This offer is tied to a specific train, has a limited availability and costs $€ 19$ for any ride within Germany. In order to emphasize the real availability (no scarcity) of this offer, actual sales figures were published on the railway's homepage. At the end of the campaign approximately 2.4 million tickets were sold.

At the same time $1 \& 1$, a leading telecommunication company, offered a new smart phone flat rate in the center of its advertising message: "The price is $€ 9.99$ per month for a 3 -fold flat rate (landline, mobile and internet)". The advertisement with the price took place as part of a nationwide print campaign.

For supermarkets, the strong focus on price is not new. Typically, for the so-called anchor products whose normal price level each consumer has in mind, it is common to reduce the prices temporarily. Especially coffee is an "action-driven business" (Fichtel, 2010). In a sales campaign in August 2015 the discounter Penny offered filter coffee "Dallmayer Prodomo" for $€ 3.99$ with a 38 Percent savings claim (the original price was stated as $€ 6.49$ ).

\subsection{Research Questions}

As these examples illustrate, there is no clear structure in what form and with what kind of framing prices are communicated. With regard to these actual price campaigns it is questionable what influence psychological factors have on the perception of prices from the perspective of consumers. Therefore, the following questions should be answered:

1. Does the price perception of sales promotions significantly change, when (a) consumers have competitor's price information available, (b) price variations are minor (1 Cent) or (c) additional framing elements (such as savings or limited availability) are used for price promotions?

2. Are the results concerning different framing techniques robust across different types of products?

3. How strong is the influence of framing techniques on price perception (mainly price cheapness and perceived value for money) compared with other factors like product involvement or price sensitivity?

4. Are the results of the experimental study consistent with the state of art wisdom concerning behavioral economics and behavioral pricing?

\section{Method}

\subsection{Procedures and Methodology}

In order to answer the research questions, an empirical study was developed and carried out, based on online interviews with $\mathrm{n}=547$ respondents (16+ years) in Germany. The recruitment was handled via online access panel. A screening part at the beginning made sure that the relevant age groups as well as an adequate regional coverage was given. The interviews were conducted in September 2015 and lasted an average of about 10 minutes. For an experimental design, the online study has several advantages. First, the questionnaire software enables to introduce graphical elements (advertisements) during the interview. Second, using a randomized selection process of respondents ensures that the different experimental groups are equally distributed in terms of relevant characteristics. ${ }^{1}$ Third, the relatively large sample size allows that the individual experimental groups are staffed by more than 100 cases and thus random fluctuation is significantly reduced.

1 For the data set was examined whether in fact no correlation between relevant parameters for assessing the price image and the classification of the subjects into different experimental groups has occurred. As part of a chi-square distribution test, the null hypothesis could not be refuted. 


\subsection{Experimental Design}

The experimental design includes three different experiments (train tickets, internet flat rate, filter coffee). In each product category a systematic variation was conducted by influencing factors. In the first group in addition to the original display the subjects received more information about the prices of the competitor (price advertising with lower absolute price point was shown first). To the second group only the original price advertising was presented. In group 3 and 4 the prices and details were changed to the original display (see Table 1).

Table 1. Experimental design

\begin{tabular}{|c|c|c|c|c|}
\hline $\begin{array}{l}\text { Product } \\
\text { category }\end{array}$ & $\begin{array}{l}\text { (1) Base sales offer }+ \\
\text { offer of competitor }\end{array}$ & (2) Base sales offer & $\begin{array}{l}\text { (3) Sales offer } \\
\text { variation } \# 1\end{array}$ & $\begin{array}{l}\text { (4) Sales offer } \\
\text { variation \#2 }\end{array}$ \\
\hline \multirow{4}{*}{$\begin{array}{l}\text { (A) Train } \\
\text { Ticket }\end{array}$} & Sales offer bus journey $€ 5$ & --- & --- & -- \\
\hline & one way & & & \multirow{3}{*}{ From $€ 19$} \\
\hline & From $€ 19$ & From $€ 19$ & From $€ 18.99$ & \\
\hline & 2.4 mill. tickets sold & 2.4 mill. tickets sold & 2.4 mill. tickets sold & \\
\hline \multirow{2}{*}{$\begin{array}{l}\text { (B) Smart } \\
\text { Phone flat } \\
\text { rate }\end{array}$} & $\begin{array}{r}\text { Sales offer } € 4.99 \\
\text { per month (Brand B) }\end{array}$ & --- & --- & --- \\
\hline & $\begin{array}{r}\text { Sales offer } € 9.99 \\
\text { per month } \\
\text { (before } € 14.99 \text { ) }\end{array}$ & $\begin{array}{r}\text { Sales offer } € 9.99 \\
\text { per month } \\
\text { (before } € 14.99 \text { ) }\end{array}$ & $\begin{array}{r}\text { Sales offer } € 10.00 \\
\text { per month } \\
\text { (before } € 14.99 \text { ) }\end{array}$ & $\begin{array}{r}\text { Sales offer } € 9.99 \\
\text { per month }\end{array}$ \\
\hline \multirow{4}{*}{$\begin{array}{l}\text { (C) Filter } \\
\text { coffee }\end{array}$} & Sales offer $€ 3.69$ & \multirow[t]{2}{*}{--} & \multirow[t]{2}{*}{---} & \multirow[t]{2}{*}{---} \\
\hline & Brand C & & & \\
\hline & Sales offer $€ 3.99$ & Sales offer $€ 3.99$ & Sales offer $€ 4.00$ & Sales offer $€ 3.99$ \\
\hline & $\begin{array}{r}\text { Brand A (before } \\
€ 6.49,-38 \%)\end{array}$ & $\begin{array}{r}\text { Brand A (before } \\
€ 6.49,-38 \%)\end{array}$ & $\begin{array}{r}\text { Brand A (before } \\
€ 6.49,-38 \%)\end{array}$ & $\begin{array}{r}\text { Brand A (max. } 3 \text { items } \\
\text { per purchase) }\end{array}$ \\
\hline
\end{tabular}

The graphics used in the interview were campaigns of competing companies in the market. As train journeys currently compete with long-distance busses, a promotional campaign of the best-known provider was selected as a competitor information (Krämer \& Jung, 2014). The additional advertisements for the smartphone tariff and filter coffee are real advertisements (with very low prices) of a main competitor. In order to cover all relevant price image dimensions 7 image statements (for detailed description see Table 3) had to be evaluated (scale from $1=$ strongly agree to $6=$ strongly disagree) after the advertisements were shown.

\subsection{Data Analysis}

To examine the significance within the three sample groups and to statistically evaluate background characteristics, the repeated measures ANOVA for overall comparisons, as well Chi-Square tests were used. In order to examine differences of mean values across experimental groups a pairwise t-test for independent samples was conducted. To analyze the data SPSS version 22 was used.

\section{Results}

\subsection{Buying Decision of Consumers: Focus on Price or Brand}

Before the individual experiments were carried out, there was a brief sequence of questions covering the typical buying habits of respondents. The interviewees should indicate for different product categories whether their purchase decisions are based on price or rather on the brand/seller. As expected, these results differ across product categories ${ }^{2}$. Since it has been suggested in recent studies that price sensitivity of consumers has a strong influence on the price perception (Anderson \& Simester, 2003), it should be examined in this section, whether the sample contains typical distribution with respect to the price or brand orientation. As reference data, the study "Best for Planning" was used"; it contains representative data on shopping behavior for Germany.

While the price of beer plays a subordinate role in the purchase decision and the orientation is strongly focused on the brand, the situation is the other way around when deciding on smartphone tariffs. Here the price plays a predominant role (51\% of interviewees indicate that they mainly focus on the price). Concerning filter coffee, the distribution between price and brand-oriented consumers is rather balanced. About a quarter of respondents see the price as a decisive factor within the purchase decision, another quarter of respondents is focused on brand.

2 The aim of this procedure was to generally test, whether respondents are more price or brand sensitive in terms of general purchase behavior. Therefore, product categories such as beer or coffee machines were also shown, although they have no specific relevance for the experimental design appearing later during the interview.

3 Best for planning (b4p) is a market-media study of several German publishing houses (Axel Springer, Bauer Media Group, Gruner + Jahr and Hubert Burda Media). Overall, 30,000 interviews are conducted per year. The results are publicly available. 
Table 2. Relevance of price and brand within the purchase decision (\% of respondents)

\begin{tabular}{lcccc}
\hline $\begin{array}{l}\text { Product } \\
\text { category* }\end{array}$ & $\begin{array}{c}\text { Price } \\
\text { focus** }\end{array}$ & $\begin{array}{c}\text { Price \& } \\
\text { brand }\end{array}$ & $\begin{array}{l}\text { Brand } \\
\text { focus }\end{array}$ & $\begin{array}{c}\text { Do not buy / Do not } \\
\text { know }\end{array}$ \\
\hline Beer & $11 \%(11 \%)$ & $25 \%(25 \%)$ & $42 \%(32 \%)$ & $22 \%(33 \%)$ \\
Filter coffee & $24 \%(18 \%)$ & $32 \%(36 \%)$ & $24 \%(34 \%)$ & $20 \%(12 \%)$ \\
Coffee machine & $28 \%(28 \%)$ & $40 \%(42 \%)$ & $19 \%(18 \%)$ & $13 \%(13 \%)$ \\
Flat rate (cellphone) & $51 \%(--\%)$ & $26 \%(---\%)$ & $13 \%(--\%)$ & $33 \%(--\%)$ \\
\hline
\end{tabular}

* Question: When you think of the following products, do you pay attention rather to brand or to price? Categories: (1) mainly price, (2) rather price, (3) both price and brand, (4) rather brand, (5) mainly brand, (6) I do not buy this product, (7) No answer.

** Results of own study (reference study b4p 2014).

\subsection{Experiment (A) with Train Tickets}

As shown in Table 3, the evaluation of price image statements is robust across experimental groups. While significant differences occur in terms of evaluating the ad as decoy or as raising clear expectations, important image sub dimensions such as cheapness ("is cheap") or price-performance-ratio ("is good value for money") do not significantly differ. Whether there is additional information on prices of competitors (potential anchor-effect), or whether the price is "From $€ 18.99$ " instead of "From $€ 19$ " or whether there is additional information on tickets already sold (potential additional framing), there is no measureable effect concerning mean values. ${ }^{4}$ Overall, the sub dimension transparency and clarity of expectation are assessed particularly critical.

Table 3. Price image evaluation sales offer train tickets

\begin{tabular}{|c|c|c|c|c|}
\hline Sales offer* & $\begin{array}{c}\text { (1) Base sales offer }+ \\
\text { offer of competitor } \\
n=140\end{array}$ & $\begin{array}{c}\text { (2) Base sales } \\
\text { offer } \\
n=137 \\
\end{array}$ & $\begin{array}{l}\text { (3) Sales offer } \\
\text { variation \#1 } \\
n=143 \\
\end{array}$ & $\begin{array}{l}\text { (4) Sales offer } \\
\text { variation \#2 } \\
n=127 \\
\end{array}$ \\
\hline$\ldots$ is cheap & $2.7(-0.1) \mathrm{p}=0.75$ & $2.8(--)$ & $3.0(0.2) \mathrm{p}=0.28$ & $2.8(-0.1) \mathrm{p}=0.24$ \\
\hline$\ldots$ is transparent & $3.8(-0.2) \mathrm{p}=0.31$ & $4,0(--)$ & $4.0(0.0) p=0.97$ & $3.8(-0.1) p=0.28$ \\
\hline ... good value for money & $3.0(-0.2) p=0.27$ & $3.2(--)$ & $3.2(0.0) \mathrm{p}=0.95$ & $3.1(0.1) \mathrm{p}=0.59$ \\
\hline$\ldots$ is fair & $3.0(-0.1) p=0.64$ & $3.1(--)$ & $3.3(0.2) \mathrm{p}=0.32$ & $3.3(0.4) \mathrm{p}=0.22$ \\
\hline ... clear expectation & $3.5(-0.3) p=0.07$ & $3.8(--)$ & $3.9(0.1) \mathrm{p}=0.50$ & $3.7(0.0) \mathrm{p}=0.55$ \\
\hline$\ldots$ is a decoy & $2.5(0.5) p=0.08$ & $2.0(--)$ & $2.3(0.3) p=0.09$ & $2.4(0.5) p=0.02$ \\
\hline Supplier is & $3.4(0.3) \mathrm{p}=0.11$ & $3.1(--)$ & $3.4(0.3) \mathrm{p}=0.15$ & $3.1(0.2) \mathrm{p}=0.72$ \\
\hline
\end{tabular}

inexpensive

* Question: Please rate the following statements to this ad: Please use a scale from $1=$ I completely agree to $6=\mathrm{I}$ completely disagree. Values presented in order of occurrence: Mean (absolute deviation from base sales offer), significance.

While no significant results are revealed between the experimental groups at the price-image factors such as cheapness and price-performance-ratio, this is the case with the factors age and product usage, respectively. Here clear dependencies arise with a high significance (for both attributes $\mathrm{p}<0.00$ ). These results are consistent with other empirical findings (Krämer, 2015a) that also confirm that in particular non-users and younger consumers assess the German railway relatively critically (see Table 4 ).

Table 4. Perceived cheapness of promoted train ticket prices depending on rail usage and age

\begin{tabular}{lccc}
\hline \multirow{2}{*}{ Perceived cheapness* } & Heavy-Users & Low-/Medium-Users & Non-Users \\
& Rail & Rail & $36.5 \%$ \\
\hline Top-2 (agreement) & $59.9 \%$ & $50.2 \%$ & $41.1 \%$ \\
Indifferent & $39.3 \%$ & $39.8 \%$ & $22.4 \%$ \\
Low-2 (disagreement) & $6.8 \%$ & $10.0 \%$ & Age: $60+$ years \\
\hline Perceived cheapness & Age: $<30$ years & Age: $30-59$ years & $49.2 \%$ \\
\hline Top-2 (agreement) & $36.5 \%$ & $45.5 \%$ & $34.1 \%$ \\
Indifferent & $57.7 \%$ & $41.0 \%$ & $16.7 \%$ \\
Low-2 (disagreement) & $5.8 \%$ & $13.5 \%$ & \\
\hline
\end{tabular}

* Question: Please rate the following statements to this ad: Please use a scale from $1=$ I completely agree to $6=\mathrm{I}$ completely disagree.

\subsection{Experiment (B) with Smart Phone Flat Rate}

As shown in Table 5, the evaluation of price image statements is even more robust across experimental groups concerning price ads for smartphone flat rates. Again, results for image sub dimensions such as cheapness ("is cheap") or price-performance-ratio ("is good value for money") do not significantly differ. Whether there is additional information on prices of competitors (potential anchor-effect), which is almost 50\% lower, or whether the price is $€ 10.00$ instead of $€ 9.99$ (potential "left-digit-effect") or whether there is additional information on savings compared

4 It should be noted that German rail typically communicated anchor prices like "From €29" indicating the lowest possible price point for consumers without discount card. Effective prices paid by travellers may vary according to their booking profile. 
with usual sales prices (potential additional framing), there is no measureable effect concerning mean values. Overall, the level of assessment is lower (less critical) compared with experiment A (train tickets).

Table 5. Price image evaluation sales offer smart phone flat rate

\begin{tabular}{|c|c|c|c|c|}
\hline Sales offer* & $\begin{array}{c}\text { (1) Base sales offer }+ \\
\text { offer of competitor } \\
n=150\end{array}$ & $\begin{array}{c}\text { (2) Base sales } \\
\text { offer } \\
n=137\end{array}$ & $\begin{array}{l}\text { (3) Sales offer } \\
\text { variation } \# 1 \\
n=125 \\
\end{array}$ & $\begin{array}{l}\text { (4) Sales offer } \\
\text { variation \#2 } \\
n=135 \\
\end{array}$ \\
\hline$\ldots$ is cheap & $2.5(0.1) \mathrm{p}=0.65$ & $2.4(--)$ & $2.2(-0.2) \mathrm{p}=0.72$ & $2.4(0.0) \mathrm{p}=0.87$ \\
\hline$\ldots$ is transparent & $3.0(-0.2) \mathrm{p}=0.23$ & $3.2(--)$ & $3.2(0.0) \mathrm{p}=0.78$ & $3.2(0.0) \mathrm{p}=0.69$ \\
\hline ... good value for money & $2.6(0.0) \mathrm{p}=0.61$ & $2.6(--)$ & $2.5(-0.1) p=0.50$ & $2.6(0.0) \mathrm{p}=0.98$ \\
\hline$\ldots$ is fair & $2.7(-0.1) \mathrm{p}=0.50$ & $2.8(--)$ & $2.8(0.0) \mathrm{p}=0.87$ & $2.7(-0.1) p=0.78$ \\
\hline ... clear expectation & $3.1(0.1) \mathrm{p}=0.78$ & $3.2(--)$ & $3.1(-0.1) \mathrm{p}=0.73$ & $3.1(-0.1) p=0.54$ \\
\hline$\ldots$ is a decoy & $2.7(0.3) \mathrm{p}=0.10$ & $2.4(--)$ & $2.3(-0.1) \mathrm{p}=0.47$ & $2.6(0.2) \mathrm{p}=0.26$ \\
\hline $\begin{array}{l}\text { Supplier is } \\
\text { inexpensive }\end{array}$ & $2.4(0.0) \mathrm{p}=0.58$ & $2.4(--)$ & $2.4(0.0) \mathrm{p}=0.63$ & $2.5(0.1) \mathrm{p}=0.29$ \\
\hline
\end{tabular}

* Question: Please rate the following statements to this ad: Please use a scale from $1=$ I completely agree to $6=\mathrm{I}$ completely disagree. Values presented in order of occurrence: Mean (absolute deviation from base sales offer), significance.

In addition to measuring the impact of experimental factors on the price perception, further dependencies were analyzed. Respondents who described themselves as rather brand-oriented showed a particularly positive evaluation (Chi-Square: $\mathrm{p}<0.00$ ). Top-2 evaluations concerning cheapness reach $74 \%$, while the corresponding share in the group of price-oriented consumers amounts to $54 \%$ (Table 6). A similar dependency can be found for the perceived value for money, although with a lower level of agreement ${ }^{5}$.

Table 6. Perceived cheapness of promoted smartphone flat rate depending consumer focus

\begin{tabular}{lccc}
\hline Perceived cheapness & $\begin{array}{c}\text { Price focus } \\
(\mathrm{n}=232)\end{array}$ & $\begin{array}{c}\text { Price \& brand } \\
(\mathrm{n}=171)\end{array}$ & $\begin{array}{c}\text { Brand focus } \\
(\mathrm{n}=82)\end{array}$ \\
\hline Top-2 (agreement) & $53.9 \%$ & $63.2 \%$ & $74.4 \%$ \\
Indifferent & $38.4 \%$ & $30.4 \%$ & $19.5 \%$ \\
Low-2 (disagreement) & $7.7 \%$ & $6.4 \%$ & $6.1 \%$ \\
\hline & Question: Please rate the following statements to this ad: Please use a scale from 1= I completely agree to 6= I completely disagree.
\end{tabular}

One explanation for the particularly positive assessment of cheapness in the group of brand-oriented consumers could be that the surprise-effect of the aggressive price promotion is particularly strong here. Since the seller is a reseller of network capacity, the displayed price level of about $10 €$ per month for the smartphone flat price offer is at least $50 \%$ below the typical prices offered by branded German network companies (Telekom, Vodafone, O2). It should be noted that $1 \& 1$ 's special offer was embedded in an overarching brand campaign.

\subsection{Experiment (C) with Filter Coffee}

Unlike the previous two experiments, the third experiment (price advertising for filter coffee) at least partially shows expected results. While presenting a competitor's ad (promotional ad of another discount market with a price of $€ 3.69$ per 500 grams filter coffee) has no significant effect on the assessment of perceived cheapness and value for money of the base product, there are clear differences when the filter coffee (original "base" offer) is offered for slightly higher price of $€ 4.00$ instead of $€ 3.99$. Clearly, small changes in price lead to a significantly worse assessment of price cheapness and value for money (see Table 7). Therefore, at least one experimental design shows results, which are consistent with the "left-digit-effect", frequently promoted in the academic literature. The differences can be explained by the theory of price threshold (Simon, 2013). When consumers get used to prices as $€ 3.99$, this can lead to strong reactions when exceeding this threshold.

Also a framing of the offer by limiting the purchasable quantity per buyer does not lead to changes in price image values compared to the base offer. One could expect that a limited availability would communicate a shortage of the product and thus a higher value from the customer's perspective.

A strong dependency between age of the interviewees and the assessment of the perceived cheapness is measured. Approval (\% top-2) is highest in the age group of seniors with $67 \%$, lowest in the age group of respondents younger than 30 years. This might be explained by a lower involvement of younger consumers towards filter coffee (affinity for coffee capsules, etc.).

\footnotetext{
5 For all 3 Product categories it can be stated that there is a strong $(r>0.5)$ and significant $(p<0.00)$ correlation between the first five statements.
} This does not apply to the last two statements. 
Table 7. Price image evaluation sales offer filter coffee

\begin{tabular}{|c|c|c|c|c|}
\hline Sales offer* & $\begin{array}{l}\text { (1) Base sales offer }+ \\
\text { offer of competitor } \\
n=147\end{array}$ & $\begin{array}{c}\text { (2) Base sales } \\
\text { offer } \\
n=135\end{array}$ & $\begin{array}{l}\text { (3) Sales offer } \\
\text { variation \#1 } \\
n=133\end{array}$ & $\begin{array}{l}\text { (4) Sales offer } \\
\text { variation } \# 2 \\
n=132\end{array}$ \\
\hline$\ldots$ is cheap & $2.3(0.0) \mathrm{p}=0.72$ & $2.3(--)$ & $2.7(-0.4) p=0.01$ & $2.5(0.2) \mathrm{p}=0.14$ \\
\hline$\ldots$ is transparent & $2.4(0.2) \mathrm{p}=0.22$ & $2.2(--)$ & $2.2(0.0) \mathrm{p}=0.83$ & $2.3(0.1) \mathrm{p}=0.49$ \\
\hline$\ldots$ good value for money & $2.3(0.1) \mathrm{p}=0.75$ & $2.2(--)$ & $2.5(0.3) p=0.07$ & $2.3(0.1) \mathrm{p}=0.52$ \\
\hline$\ldots$ is fair & $2.4(0.0) \mathrm{p}=0.97$ & $2.4(--)$ & $2.5(0.1) \mathrm{p}=0.58$ & $2.5(0.1) p=0.65$ \\
\hline ... clear expectation & $2.1(0.0) \mathrm{p}=0.88$ & $2.1(--)$ & $2.0(-0.1) \mathrm{p}=0.27$ & $2.0(-0.1) \mathrm{p}=0.25$ \\
\hline$\ldots$ is a decoy & $3.2(0.0) \mathrm{p}=0.85$ & $3.2(--)$ & $3.7(0.5) p=0.03$ & $3.3(0.1) p=0.70$ \\
\hline $\begin{array}{l}\text { Supplier is } \\
\text { inexpensive }\end{array}$ & $3.2(-0.5) p=0.07$ & $3.7(--)$ & $3.7(0.0) \mathrm{p}=0.88$ & $3.4(-0.3) \mathrm{p}=0.19$ \\
\hline
\end{tabular}

* Question: Please rate the following statements to this ad: Please use a scale from $1=\mathrm{I}$ completely agree to $6=\mathrm{I}$ completely disagree. Values presented in order of occurrence: Mean (absolute deviation from base sales offer), significance.

\subsection{Overall Results and Conclusions}

Against the background of the discussion about behavioral pricing, often dominated by the impression, influencing consumers' price perception is possible through seemingly minor changes in the presentation of prices the results of the present experimental study are very robust.

Only for the product category filter coffee significant influences on important price image dimensions like perceived cheapness and value for money are detected. In the experiments with train tickets or smartphone flat rates no significant influences due to experimental factors like competitive prices, anchor prices, "left-digit-effects" or availability constraints can be identified.

The "left-digit-effect" was displayed by changes between groups 2 and 3 (€9.99 vs. $€ 10.00$ for smartphone flat rate and $€ 3.99$ vs. $€ 4.00$ for filter coffee) and can only be confirmed in one experiment. This suggests that it is not a fundamental effect, but depends on the product. As Choi, J. et al. (2014) stated, "people are more likely to choose hedonic over utilitarian products when they have odd-ending prices". This gives a hint that conventional understanding of psychological pricing has to be adjusted. Since there is no evidence of a clear structure to optimize price signaling, a more pragmatic approach to pricing is recommended.

Overall, the degree of price image level increases from experiment A to C. Consumers' evaluation of railway special fares is positive, but more critical compared with smart phone tariffs and filter coffee sales promotions as presented in this study. However, it has to be considered that the product complexity and need for explanation of the products is different: highest for the train tickets and lowest for the filter coffee.

As illustrated, unique drivers for the price perception can be determined, which act stronger than the psychological factors that varied across experimental groups: age, product affinity and price sensitivity of consumers. The effects of these drivers, however, have a strong variance by product category.

\section{Discussion}

An irritating result arises from the train tickets experiment between the versions from $€ 19$ (group 2) and from $€ 18.99$ (group 3). Not only that the lower price has no positive impact on the perceived cheapness, as it might be expected, the price reduction even leads to a significant deterioration in the perception of the price (see Figure 1). While the agreement on cheapness for the price of $€ 19$ was $48 \%$, the corresponding figure drops to $37 \%$ at the comparatively lower price of $€ 18.99$. Here, possibly the transcription of the pricing information works differently. Hence, one could assume that it is easier for the consumers to transcript $€ 19$ as inexpensive compared to the price of $€ 18.99$ (for rail prices in Germany price endings with 99 are rather uncommon). The weak evaluation of the $€ 18.99$ priced train ticket compared to the base offer of $€ 19$ might also be explained due to a different quality perception (Balan, 2013).

Coulter, Choi, \& Monroe (2012) demonstrate that including commas (e.g. \$1.599 vs. \$1599) and cents (e.g., $\$ 1599.85$ vs. \$1599) in Arabic written form (i.e. how it is perceived visually) can change how the price is encoded and represented verbally in a consumer's memory. Other studies suggest consumers appear to favor round numbers when paying for goods and services (Lynn, Flynn \& Helion, 2013) and adopting round-pound prices may be more effective (Bray \& Harris, 2006).

Finally, the relationship between the perceived cheapness of the investigated product and the general inexpensiveness of the provider should be emphasized. For both product categories, train tickets as well as filter coffee, clear differences between the two parameters are determined. The favorability of the product is assessed significantly more positively than the inexpensiveness of the provider. This is reasonable in case of train tickets, as 
in Germany the price image of the national rail carrier is relatively poor. Concerning coffee this result is sobering, since coffee is regarded as anchor product and it is expected that consumers transfer their product price evaluation over to the general product portfolio of the supermarket. In contrast, in case of the smartphone flat rate both parameters are relatively close: the sales offer is perceived inexpensive, so is the seller. This is probably explained by the fact that the supplier has a relatively limited portfolio of products.

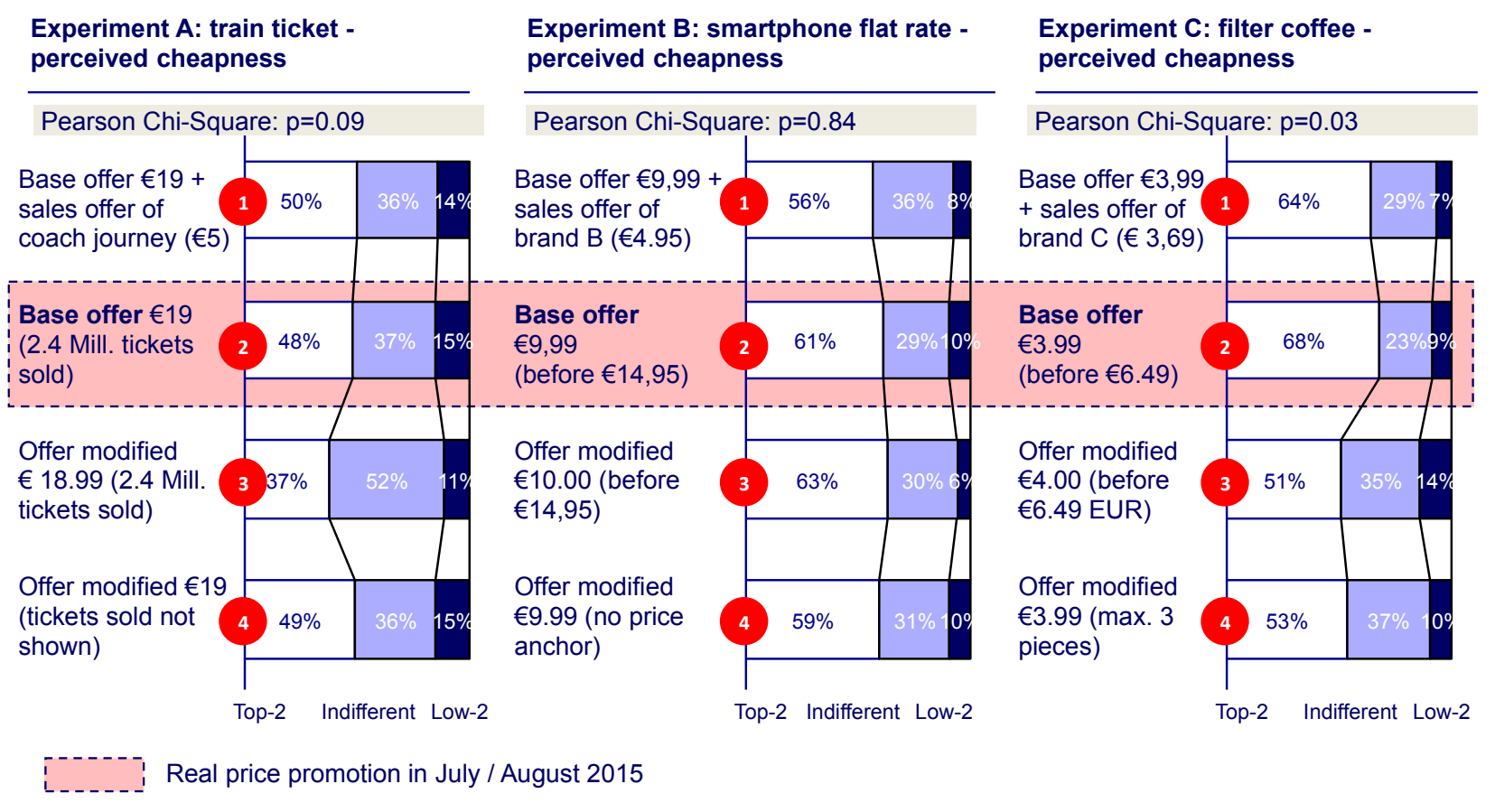

Figure 1. Consumers' perceived cheapness (3 categories, 4 experimental groups)

The present study confirms what well-known pricing researchers have already expressed: the effect price changes have on purchase behavior are still unknown (Adaval, 2013) or strongly influenced by contextual factors (Cheng \& Monroe, 2013). The large number of publications does not result in a uniform theory of behavioral pricing.

\section{Outlook and Final Remarks}

While the proliferation of studies ${ }^{6}$ on behavioral pricing and thereby partly spectacular results suggest that it is easily possible to influence parameters in the consumers' price perceptions, there are also critics to behavioral pricing: One criticism is directed at the sometimes contradictory results of often cited "theories" (such as the endowment effect). This shows that the implementation of conducted experiments has a strong influence on the study results, so that the reliability in total is low (Plott \& Zeiler, 2005). The high elasticity of interpretation of results leads to another problem that Beck (2015) describes as follows: "What is the benefit of a theory which predicts no clear results?"

When Choi, J. et al. (2014) stated, that "... there is evidence, that there is no clear structure to optimize price signaling" one might ask for recommendations on a more pragmatic approach to pricing. Considering the following guideline might help (Krämer, 2015b):

(1) Continuous segmentation: the increasing speed of market changes requires a modified segmentation of the market in two directions: First, apply continuous customer segmentation instead of an ad-hoc approach. Second, avoid multiple, concurrent and potentially contradictory segmentations (Williams, 2014). To ensure that the segmentation can be efficiently used for pricing decisions, the segmentation should also be based on the price sensitivity and willingness to pay of customers (Krämer \& Burgartz, 2015).

(2) No blind faith for results of market simulation models: elaborate survey methods such as conjoint measurement not only provide utility values for different features and their attributes. Moreover, these can be used as input data for simulation models. However, the quality of the results strongly depends on the inputs and the survey design (used attributes and levels). Therefore, market simulation models can be helpful, as long as the users are aware of the limitations (they will not fully reflect the price psychological effects).

6 Simon (2013) notes that since the award of the Nobel Prize to Kahneman and Tversky for their work on Prospect Theory "the number of authors and publications dedicated to behavioral economic problems explosively swells." 
(3) Testing under real market conditions: if possible, hypotheses should first be developed regarding the expected price elasticity and price-demand relationship and then reviewed in a subsequent targeted market testing under real purchasing conditions. As Thomke \& Manzi (2014) described in a business case: "when... executives investigated a new pricing for a product sold by weight, the results were unequivocal. By far, the best price was for a quarter pound of the product, and that price was for an amount that ended in $\$ .25$. That result went sharply against the grain of conventional wisdom, which typically calls for prices ending in 9 , such as $\$ 4.99$ or $\$ 2.49$."

\section{Acknowledgements}

The author is grateful to Rogator AG, Nuremberg, for the provision of survey software, the programming of the questionnaire and the complete data management including access to the online panel. Many thanks also Dr. Gerd Wilger and Dr. Robert Bongaerts (exeo) as well as Martin Jung for valuable suggestions and substantive input to the study.

\section{References}

Adaval, R. (2013). The utility of an information processing approach for behavioral price research. AMS Rev, 3, 120-134. http://dx.doi.org/10.1007/s13162-013-0045-x

Anderson, E. T., \& Simester, D. I. (2003). Effects of $\$ 9$ Price Endings on Retail Sales: Evidence from Field Experiments, Quantitative Marketing and Economics, 1, 93-110. http://dx.doi.org/10.1023/A:1023581927405

B4P: best for planning Data set 2014. Retrived from https://online.mds6.de/mdso6/b4p.php

Balan, C. (2013). Research on Odd Prices. In: Hinterhuber, A., Liozu, S. (eds.), Innovation in Pricing. Abingdon, 376-392.

Beck, H. (2015). Zeit für die Euphoriebremse: Zur Theorie, Empirie, Ethik und Politik der Behavioral Economics. http://www.marktforschung.de/hintergruende/themendossiers/behavioral-economics/dossier/?tx_news_pi1[news]= 425738\&cHash $=5 \mathrm{~d} 341 \mathrm{de} 6 \mathrm{bcaf} 6481292 \mathrm{~d} 504 \mathrm{c} 37 \mathrm{a} 234 \mathrm{a} 1$

Bray, J. P., \& Harris, C. (2006). The Effect of 9-Ending Prices on Retail Sales: A Quantitative UK Based Field Study. Journal of Marketing Management, 22(5-6), 601-617, http://dx.doi.org/10.1362/026725706777978631

Choi, J. et al. (2014). The odd-ending price justification effect: The influence of price-endings on hedonic and utilitarian consumption. Journal of the Academy of Marketing Science, 42(5), 1-13, September. http://dx.doi.org/ $10.1007 / \mathrm{s} 11747-014-0369-6$

Coulter, K. S., Choi, P., \& Monroe, K. B. (2012). Comma N' cents in pricing: The effects of auditory representation encoding on price magnitude perceptions. Journal of Consumer Psychology, 22(3), 395-407. Http://dx.doi.org/10.1016/j.jcps.2011.11.005

Fichtel, K. (2010). Billiger Kaffee als Lockangebot beim Discounter. http://www.abendblatt.de/wirtschaft/article108530206/Billiger-Kaffee-als-Lockangebot-beim-Discounter.html

Gaston, B. C. (2011). Consumer Preferences for 99-ending prices: The mediating role of price consciousness”, Working Paper, Universidad Carlos III de Madrid, http://portal.uc3m.es/portal/page/portal/dpto_economia_empresa/home/research/Research\%20documents/working _papers/ewp2011/1105.pdf

Helson, H. (1964). Adaptation-level theory. New York: Harper \& Row.

Janiszewski, C., \& Lichtenstein, D. R. (1999). A Range Theory Account of Price Perception. Journal of Consumer Research, 25 (4), 353-368. http://dx.doi.org/10.1086/209544

Krämer, A. (2015a). Rabatt- und Kundenbindungskarten im Personenverkehr - Länderübergreifende Analyse zu den Bahn-Rabattkarten in der DACH-Region, ZEVrail, 139(9), 341-347.

Krämer, A. (2015b). Pricing in a VUCA World - How to Optimize Prices, if the Economic, Social and Legal Framework Changes Rapidly. In: Mack et al. (eds.), Managing in a VUCA World. Springer, New York, 115-128. http://dx.doi.org/10.1007/978-3-319-16889-0

Krämer, A., \& Burgartz, T. (2015). Customer Value Controlling - Combining Different Value Perspectives. Business and Management Studies, 1(2), 11-19, http://dx.doi.org/10.11114/bms.v1i2.814

Krämer, A., \& Jung, M. (2014). Zwischen Preiswettbewerb und Preiskampf-Das Spannungsfeld zwischen Nachfrageboom und Preiserosion bei Reisen mit Fernlinienbussen. Internationales Verkehrswesen, 66(4), 58-60.

Ku, H., Kuo, C., \& Kuo, T. (2012). The Effect of Scarcity on the Purchase Intentions of Prevention and Promotion Motivated Consumers. Psychology and Marketing, 29(8), 541-548. http://dx.doi.org/10.1002/mar.20541 
Larson, R. B. (2014). Psychological Pricing Principles for Organizations with Market Power. Journal of Applied Business and Economics, 16(1), 11-25.

Lynn, M., Flynn S. M., \& Helion, C. (2013). Do consumers prefer round prices? Evidence from pay-what-you-want decisions and self-pumped gasoline purchases. Journal of Economic Psychology, 36(June), 96-102, http://dx.doi.org/10.1016/j.joep.2013.01.010

Plott, C. R., \& Zeiler, K. (2005). The Willingness to Pay-Willingness to Accept Gap, the "Endowment Effect" Subject Misconceptions, and Experimental Procedures for Eliciting Valuations. The American Economic Review, 95(3) 530-545. http://dx.doi.org/10.1257/0002828054201387

Schindler, R. M., \& Kibarian, T. M. (2001). Image Communicated by the Use of 99 Endings in Advertised Prices. Journal of Advertising, 30(Winter), 95-99. http://dx.doi.org/10.1080/00913367.2001.10673654

Simon, H. (2013). Preisheiten - Alles, was Sie über Preise wissen müssen. Campus, Frankfurt.

Thomas, M., \& Morwitz, V. (2005). Penny Wise and Pound Foolish: The Left-Digit Effect in Price Cognition, Journal of Consumer Research 32(1), 54-64. http://dx.doi.org/10.1086/429600

Thomke, S., \& Manzi, J. (2014). The Discipline of Business Experimentation, HBR. December 2014, 71-79.

Williams, D. S. (2014): Connected CRM - Implementing a Data-Driven, Customer-Centric Business Strategy, Wiley, Hoboken.

\section{$(\mathrm{cc})$ EY}

This work is licensed under a Creative Commons Attribution 3.0 License. 